\title{
Effects of clipping and sheep grazing on dyers woad
}

\author{
NEIL E. WEST AND KASSIM O. FARAH
}

\section{Abstract}

Dyers woad (Isatts tinctoria L.) is an introduced cruciferous forb that is rapidly expanding on intermountain rangelands and is apparently reducing production and regeneration of more desirable forage plants. Mechanical and chemical controls are expensive as well as having deleterious eficets on nontarget species. Limitations to controlling this noxiows weed by early spring grazing were investigated with clipping experiments at 1 site in the Wasatch foothills of northern Utah. These results were compared with actual utilization of woad by sheep at a poor condition example of that site. Significant mortality and reduction in reproductive performance occurred when at least $60 \%$ of the aboveground phytomass had been removed on or after $23 \mathrm{May}$. Clippling twice, to remove as much as $90 \%$ of aboveground tissue before 23 May, did not significantly affect woad mortality, percent flowering, or fruit production. Sheep did not graze this weed heavily enough at late enough dates to significantly affect mortality or seed production. Even on a poor condition range, these animals switched to other forages after about 15 May. Stocking rates required to restrict dyers woad at our clipping site would likely result in further range deterioration. More host-specific biological control agents should be examined.

Key Words: Isatis tinctoria, clipping, biological control, utilization by sheep

Dyers woad (Isatis tinctoria L.) is an introduced cruciferous forb that has been rapidly spreading in the croplands and rangelands of northern Utah and surrounding states (Farah et al. 1988). Young and Evans (1977) and Evans and Chase (1981) concur that dense infestations can substantially reduce forage production and regeneration of more desirable species. Chemical and mechanical controls exist for croplands (Evans and Gunnell 1982, King and Evans 1983). Damage to nontarget, desirable forage plants, steepness and rockiness of most range sites where woad occurs, and questionable economic feasibility limit use of these chemical and mechanical controls on rangelands. Development of a biological control would thus be desirable. Others have obtained some success with livestock as control agents of other noxious rangeland weeds (Scifres 1981, Brock 1988).

Limitations to controlling dyers woad by early spring grazing were investigated via clipping experiments. We sought combinations of intensity, frequency, and timing of clipping that could cause significant mortality and reduction in flowering and seed production of dyers woad. These results were compared with actual patterns of dyers woad utilization by sheep and corresponding impacts on its mortality, percent flowering, and seed production.

\footnotetext{
Authors are professor, Department of Range Science, Utah State University, Logan 84322-5230; and lecturer, Department of Range Management, University of Nairobi, Kabete campus, P.O. Box 29053 , Nairobi, Kenya. At the time of the research, the junior author was World Bank fellow and graduate research assiatant, Department of Range Science, Utah State University, Logan.

Research was funded by the Utah Agricultural Experimental Station, of which this is Journal Paper No. 3602. Authors wish to thank Ramona Rukavina for technical assistance and Dr. J.H. Richards for suggestions toward improvement of the experimental design and its analysis. Mark Jensen and J.D. Norr kindly allowed us to conduct our investigations on their land.

Manuscript accepted 24 August 1988.
}

\author{
Materials and Methods
}

Study Sites

Our experiments were conducted at 2 foothill locations on the western slope of the Wellsville Mountains, Box Elder Co., Utah. Elevations averaged about $1,500 \mathrm{~m}$. Soils there belong to the Sterling Series, a well-drained loamy skeletal, mixed mesic Typic Calcixeroll (Soil Conservation Service 1975). Estimated average precipitation is about $40 \mathrm{~cm} / \mathrm{yr}$. Average annual air temperature is $9^{\circ} \mathrm{C}$ (Soil Conservation Service 1985). Potential natural vegetation is dominated by big sagebrush (Artemisia tridentata Nutt.) and bluebunch wheatgrass [Agropyron spicatum (Pursh) Scribn. \& Smith].

Both clipping and utilization studies were located on a "mountain shallow" range site (Soil Conservation Service 1985). The clipping studies were located in an area that had not been grazed by livestock for at least 20 years. Vegetation there was in late seral or "good" condition for livestock use. Utilization studies of woad were conducted in a sheep pasture about $3 \mathrm{~km}$ to the north of the locale of the clipping studies. Although elevation, slope, exposure, soils and potential vegetation were similar at the sites used for clipping studies, a long history of early spring through fall grazing had caused retrogression to early seral or "poor" conditions for livestock use (Soil Conservation Service 1975). The major plant species there were big sagebrush, cheatgrass (Bromus tectorum L.), bulbous bluegrass (Poa bulbosa L.), broom snake weed [Gutierrezia sarothrae (Pursh) Brit. \& Rusby], gumweed [Grindelia squarrosa (Pursh) Dunal], and dyers woad.

\section{Clipping Study Procedures}

A 30 by 50 -m macroplot with a dense population of dyers woad was selected. The plot was divided into 30 rows, each 1 by $30 \mathrm{~m}$, perpendicular to the contour. Ten random locations within each row were selected and the dyers woad plant nearest to this location was marked during October, 1983, and a 1 meter tall wooden stake placed $50 \mathrm{~cm}$ to the north. Selected plants had a basal rosette of at least 3 leaves that spanned at least $4 \mathrm{~cm}$. Such plants (1): could be positively identified as dyers woad; (2) could be utilized by sheep; and (3) were likely to live to maturity (Farah et al. 1988).

The clipping regimes were of 2 intensities, $60 \%$ or $90 \%$ removal of aboveground tissue, found at the time of each clipping plus an unclipped control. The percent aboveground phytomass removed was based on rosette radius, collective leaf mid-rib lengths or stalk height, existing on the plant at the time of clipping. Concurrent studies (Farah 1987) showed strong relationships between these dimensional variables and aboveground biomass of dyers woad.

The plants were also subjected to varying frequencies of clipping at several dates during the growing season: (1) only once on 16 April 1984; (2) twice on 16 April and again on 7 May 1984; (3) three times on 16 April, 7 May, and 23 May 1984; and (4) four times on 16 April, 7 May, 23 May, and 11 June 1984. Each frequencyintensity treatment combination was replicated 30 times. Plants for each treatment were chosen at random from the entire marked population.

At each clipping date, a separate set of previously unclipped plants (intermingled with the other plants) was clipped only once at $90 \%$ intensity to determine if dyers woad was susceptible to a single, severe clipping at a certain time. Data from this treatment 
also helped to separate the interactions of frequency of clipping with time of clipping.

Data taken just before clipping included phenophase (Farah et al. 1988), rosette diameter, number of rosette leaves, and basal diameter just beneath the rosette leaves. Other data collected at later dates were stalk height, number of stalks bearing flowers, and fruit number per plant. Since clipping often retarded development, plants clipped in 1984 were observed again during the 1985 growing season. The effects observed during 1984 and cumulatively from 1984 and 1985 were analyzed separately.

The statistical design consisted of a $(2 \times 4)+1$ modified factorial with experimental units (individual plants) and treatments arranged completely at random.

A binomial chi-square analysis was used to test the effect of clipping on mortality and percent flowering of dyers woad (Cochran and Cox 1957). Ninety-five percent confidence intervals were used to detect differences in seed production and number of flowering stalks produced between treatments. A square root transformation was required to homogenize variances among treatments. For purposes of presentation, means and confidence intervals were back-transformed to the original scale (Sokal and Rohlf 1981). The multiple and single time clipping treatments were analyzed together and separately. The latter analysis made it possible to determine how much a single clipping at a given time contributed to the total effect.

\section{Utilization Study Procedures}

A site physically similar to the area of the clipping study was located in March of 1984 near the center of a sheep-grazed paddock. Ten transects, each $50 \mathrm{~m}$ long, were chosen so that they ran parallel to sheep trails (to minimize trampling impacts). These transects were marked with iron pins, driven in close to the ground surface at 5-m intervals.

Six hundred plants (rosette diameter $>6 \mathrm{~cm}$ ) were chosen in early April, 1985. Random distances along the transects were selected and then the nearest plant to that point located. Plants were further identified by colored toothpicks placed upright in the soil $5 \mathrm{~cm}$ to their north. Half the selected plants were protected from sheep grazing that season by $1-\mathrm{m}^{3}$ wire exclusion cages. These plants served as controls.

On 27 April about 150 sheep were turned into the pasture by the owner. The following observations were made biweekly (if applicable): (1) whether the woad plant was grazed; (2) lengths and widths of leaves remaining on the grazed plants (including petioles); (3) rosette diameter; (4) basal diameter; (5) number of rosette leaves; (6) number of fruits per plant; (7) fruit weight per 100 fruits; (8) mortality of individuals; and (9) phenophase.

With the exception of phenology, mortality, and reproductive variables (6 through 9), measurements of all other variables were discontinued after 20 May 1984 due to cessation of grazing by sheep on dyers woad.

A random set of 30 control plants was destructively sampled on 18 May 1984 to establish regression relationships between leaf area and leaf weight, and stalk height to stalk weight at the end of the utilization period. Regression analysis was also used to evaluate the relationship between degree of sheep utilization and various size characteristics of dyers woad. A chi-square test of independence (Steel and Torrie 1980) was used to determine the effect of grazing on mortality and percent flowering of dyers woad.

\section{Results}

\section{Phenology}

Figure 1 shows that while overall phenological development of dyers woad during 1984 was similar at both the clipping and utilization study sites, unutilized controls began flowering earlier

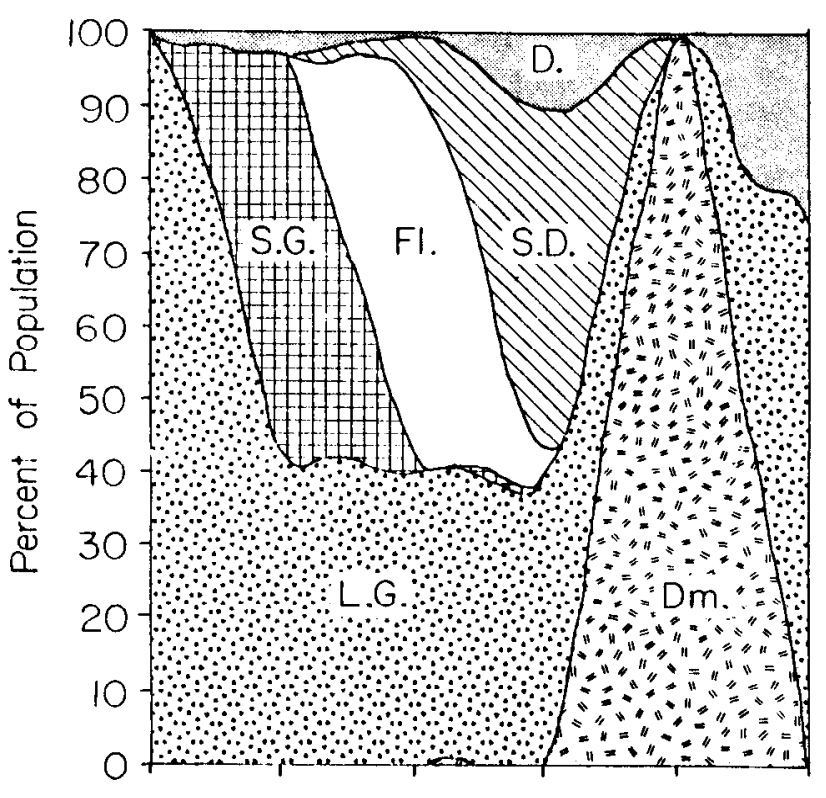

(a)
16-April
23-May
10-Aug

\section{7-May $\quad 11$-June 6 -Oct}

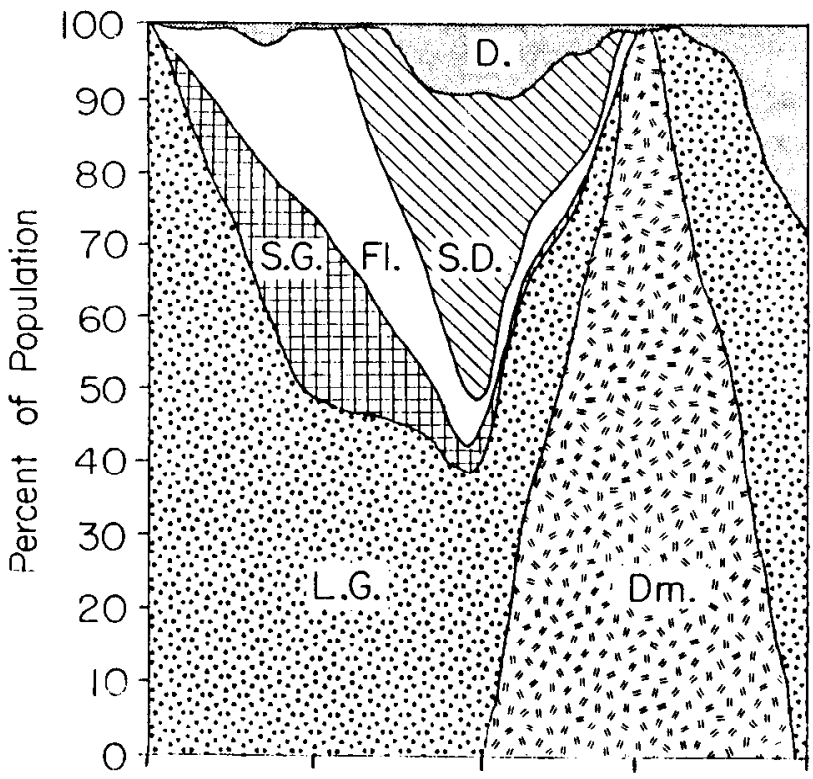
27 -April
15-June

$$
\begin{aligned}
& \text { I8-May } 13 \text {-Aug } \\
& \text { Dm.-Dormancy } \\
& \text { S.G.-G.- Leaf Growth } \\
& \text { S.D.-Seed Development }
\end{aligned}
$$

$12-\mathrm{Oct}$

Fig. 1. Percentages of marked, unclipped dyers woad populations, at the site of the clipping study (a) and at the site of the utilization study (b), in various phenological stages during spring, summer and fall of 1984. $\mathrm{n}=$ 30 in both cases.

in the sheep pasture. Since it required a week to record data at each site, data collection at the utilization study site lagged by 1 week. These phenological progressions were also similar to earlier multiyear responses presented in Farah et al. (1988). Dyers woad plants had started vegetative growth by 16 April 1984, less than 1 week 
after completion of the winter snowpack melt. Stem growth was initiated during the last week of April, while flowering began in the second week in May and peaked at about 23 May 1984. Seed formation occurred between 9 June and 15 June. By the end of June, most of the seeds had ripened.

Basal diameter of the control plants at the site of the clipping study increased between 16 April and 7 May 1984, and thereafter remained fairly constant (Fig. 2). Rosette diameter increased between 16 April and 7 May 1984, levelling off by 23 May, after

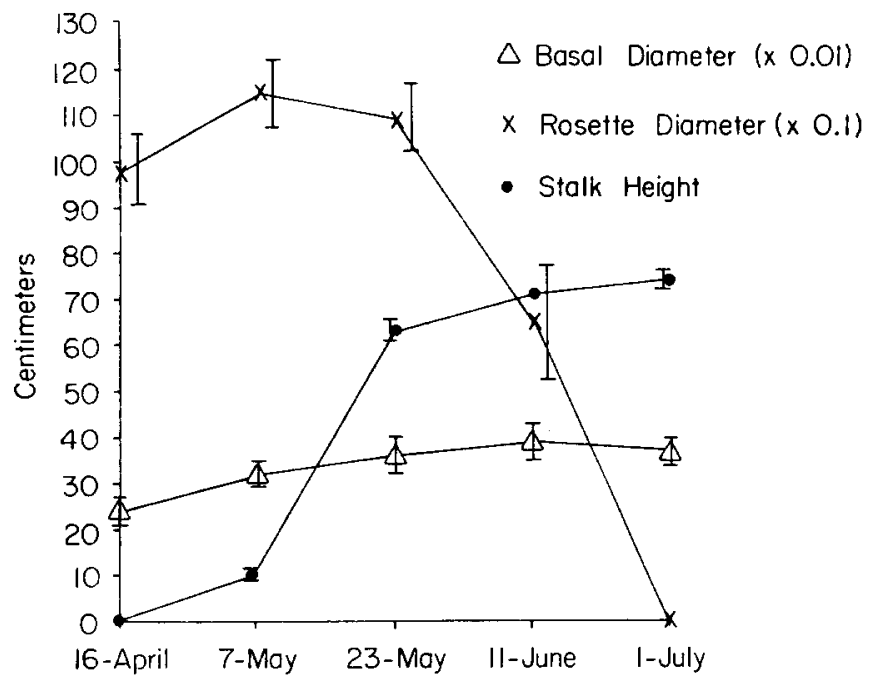

Fis. 2. Mean growth of basal diameter, rosette diameter, and flowering stalk height of marked, unclipped dyers woad plants during spring and early summer of 1984 (clipping study). $\mathrm{n}=30$ plants. Vertical lines are 95\% confidence intervals.

which it declined (Fig. 2). The decline in rosette diameter was due to withering of leaves, which accompanied the growth and development of flowering stems. Stem growth started in the last week of April. Height of flowering stalks increased rapidly between 7 May and 11 June 1984 (Fig. 2). Thus, dyers woad grows rapidly during spring, enabling it to produce seeds within 2 months after snow melt.

\section{Effects of Multiple Clipping}

During the first year (1984), there was significantly higher mortality among plants clipped at $60 \%$ (low) intensity than among unclipped controls when clipping occurred at least 3 times (Fig. 3a). There was also significantly higher mortality among plants clipped at least twice at the $90 \%$ (high) intensity, than among controls during the first year (Fig. 3a). At least 3 sequential clippings, at either $60 \%$ or $90 \%$ intensity, during the rapid growth period were required to significantly increase mortality rates over those of the controls during both years (Fig. 3b). In order to significantly reduce flowering ability of dyers woad, at least 3 sequential clipping, at either 60 or $90 \%$ intensities, were required (Fig. 4).

Mean fruit production per plant did not differ significantly between the various clipping treatments (Table 1). In other words, if plants clipped at $60 \%$ intensity 4 times during spring managed to flower, they would produce about as many fruits as the controls. When total fruit production was expressed as a percentage of the control, treatment effects on fruit production were more evident (Table 1). Fruit production of plants clipped 2 times at $60 \%$ intensity was $49 \%$ of the control, while those clipped 2 times at $90 \%$ intensity produced only $38 \%$ of that of the controls (Table 1). Mean
1984

(a)

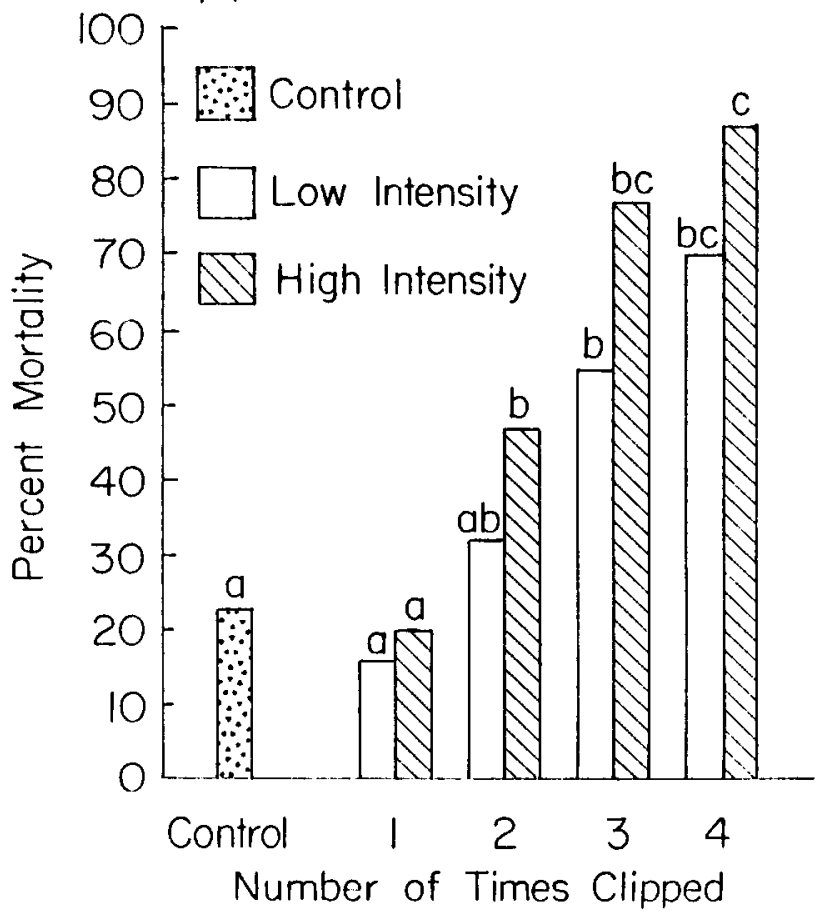

$1984+1985$

(b)

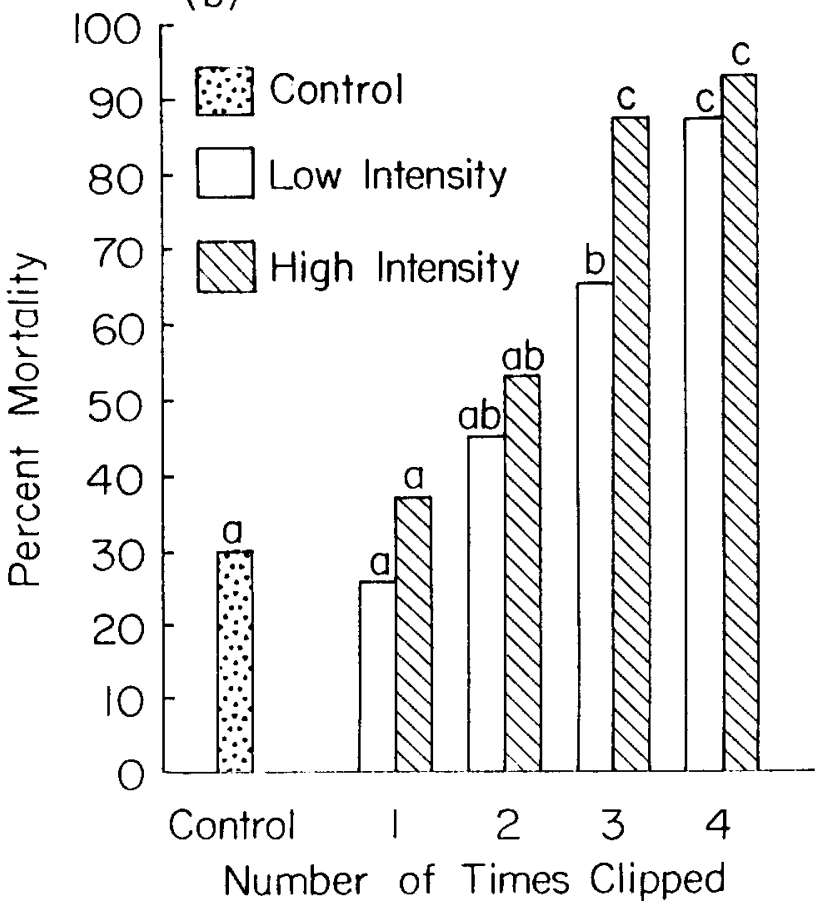

Fig. 3. Effect of multiple clipping at 2 intensities $(60 \%=l o w ; 90 \%=$ high $)$ on mean cumulative percent mortalty of dyers woad during 1984 (a) and during 1984 and 1985 combined $(b) . n=30$ plants at the beginning of the experiment. Bars with different letters are significantly different at a level of 0.05 .

individual fruit weights and number of flowering stalks per plant were statistically similar under all treatments (data not shown). 
Table 1. Fruit production by dyers woad plants clipped during the spring of 1984 at varying intensities and frequencies.

\begin{tabular}{|c|c|c|c|c|c|c|}
\hline Treatment Intensity & $\begin{array}{l}\text { Number of } \\
\text { Clippings }\end{array}$ & $\begin{array}{c}\text { Original Sample } \\
\text { Size } \\
\text { (\# of plants) }\end{array}$ & $\begin{array}{c}\text { Number of Plants } \\
\text { that } \\
\text { Fruited }\end{array}$ & $\begin{array}{c}\text { Mean Fruit } \\
\text { Production per } \\
\text { Plant }\end{array}$ & $\begin{array}{l}\text { 95\% Confidence } \\
\text { Limits }\end{array}$ & $\begin{array}{c}\% \text { of } \\
\text { Control }\end{array}$ \\
\hline $\begin{array}{c}\text { Control } \\
60 \% \\
60 \% \\
60 \% \\
60 \% \\
90 \% \\
90 \% \\
90 \% \\
90 \%\end{array}$ & $\begin{array}{l}0 \\
1 \\
2 \\
3 \\
4 \\
1 \\
2 \\
3 \\
4\end{array}$ & $\begin{array}{l}30 \\
31 \\
31 \\
31 \\
30 \\
30 \\
30 \\
30 \\
30\end{array}$ & $\begin{array}{r}20 \\
22 \\
18 \\
9 \\
5 \\
20 \\
15 \\
3 \\
1\end{array}$ & $\begin{array}{r}237 \\
223 \\
128 \\
97 \\
139 \\
174 \\
121 \\
94 \\
164\end{array}$ & $\begin{array}{r}175,318 \\
167,286 \\
83,184 \\
40,179 \\
39,301 \\
123,234 \\
72,181 \\
2,436 \\
\end{array}$ & $\begin{array}{r}100 \\
104 \\
49 \\
18 \\
15 \\
73 \\
38 \\
6 \\
3\end{array}$ \\
\hline
\end{tabular}

1984
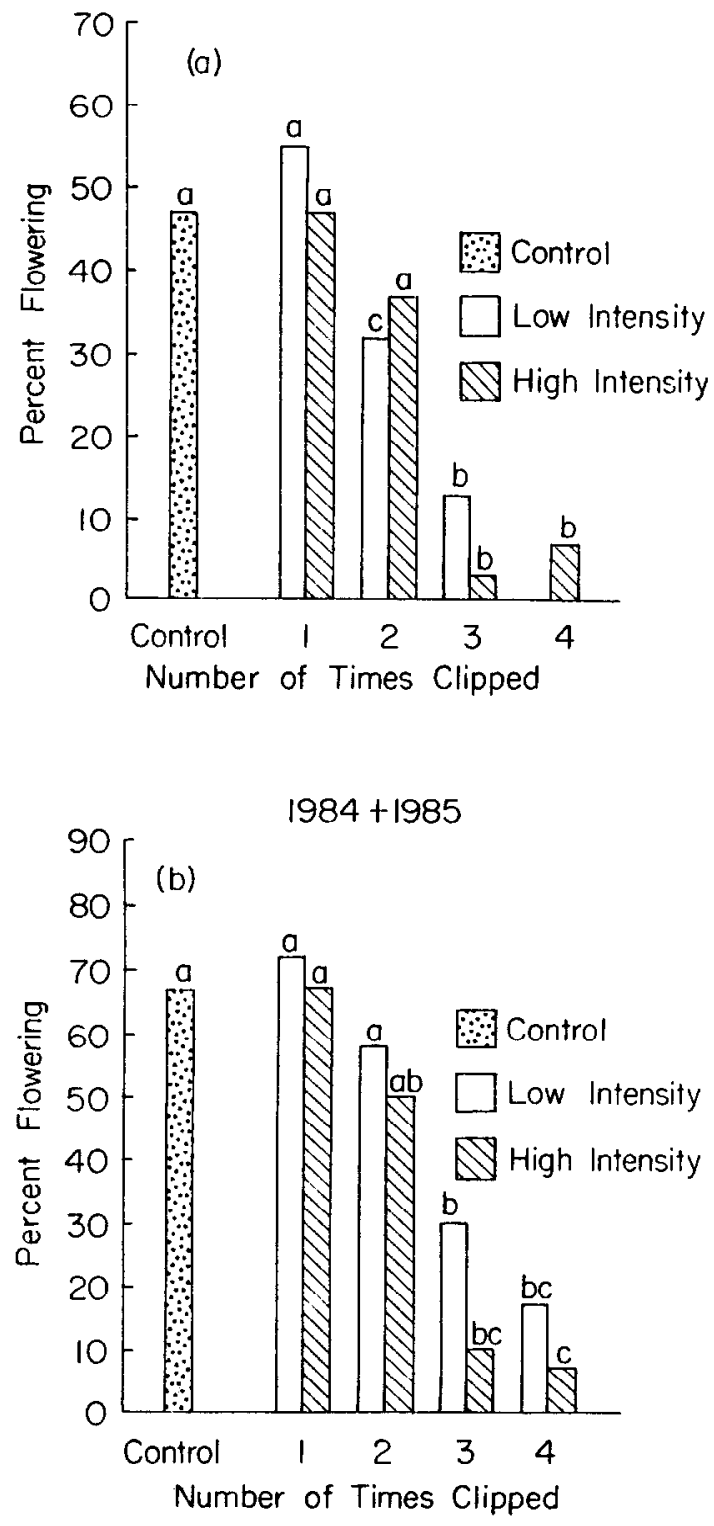

Fit. 4. Effect of multiple clipping at 2 intensities $(60 \%=$ low; $90 \%=$ high $)$ on mean comulative percent flowering of dyers woad during 1984 (a) and during 1984 and 1985 combined $(b) . \mathrm{n}=30$ plants at the beginning of the experiment. Bars with different letters are significantly different at an $\alpha$ level of 0.05 .

\section{Effects of Time of Clipping}

A set of previously unclipped plants was clipped only once at $90 \%$ intensity to determine if there was a time at which dyers woad was susceptible to a single, severe clipping. In order to achieve significant mortality over those of the controls, plants had to be clipped at $90 \%$ intensity no earlier than 23 May (Fig. 5). Single $90 \%$ clippings prior to this time did not significantly affect mortality of

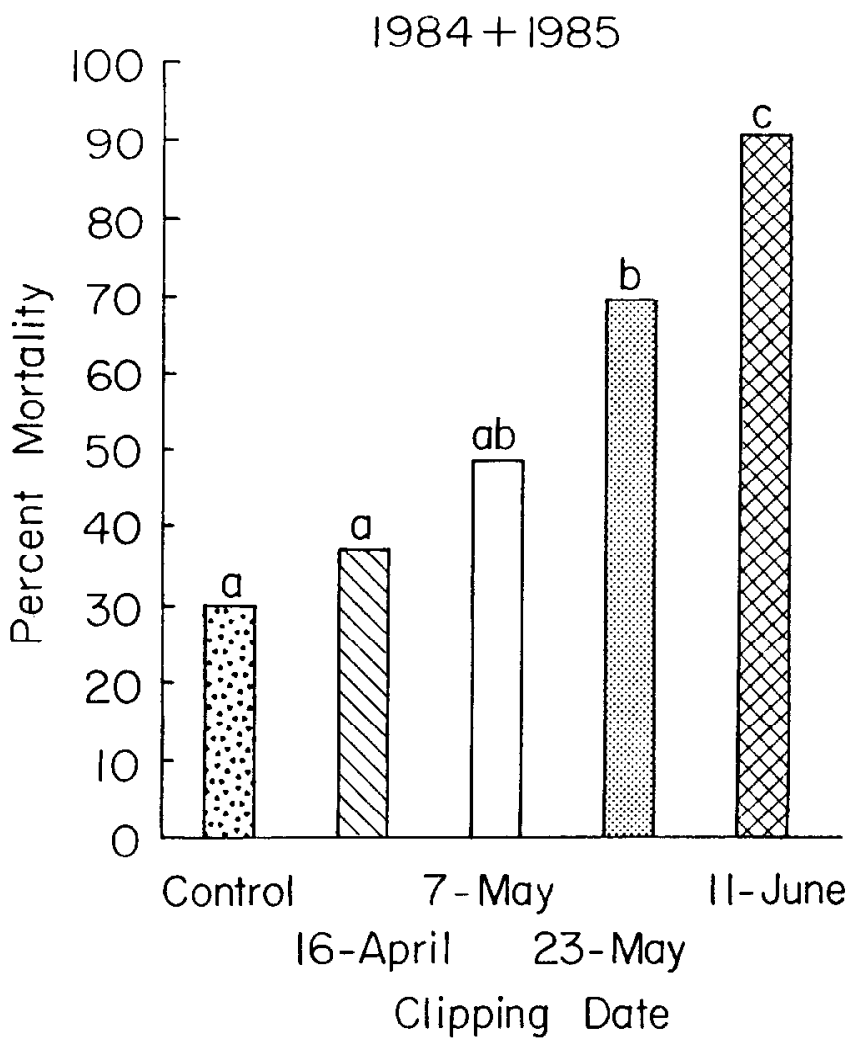

Fig. 5. Effect of time of clipping on mean cumulative percent mortality of dyers woad during 1984 (a) and during 1984 and 1985 combined (b). Plants were clipped to remove $90 \%$ of aboveground phytomass. $\mathrm{n}=30$ plants. Bars with different letters are significantly different at an $\alpha$ level of 0.05 .

dyers woad. A single heavy clipping also resulted in significant reductions in percent flowering only when plants were clipped on or after 23 May (Fig. 6). A contrast between Figures $6 a$ and b shows that clipping after 7 May delayed flowering of some plants by 1 year.

Date of clipping affected total fruit production of treated plants. Fruit production of plants clipped on 7 May and those clipped on 23 May were, respectively, $42 \%$ and $23 \%$ of the controls. As in the multiple clipping treatment, fruit production did not significantly 

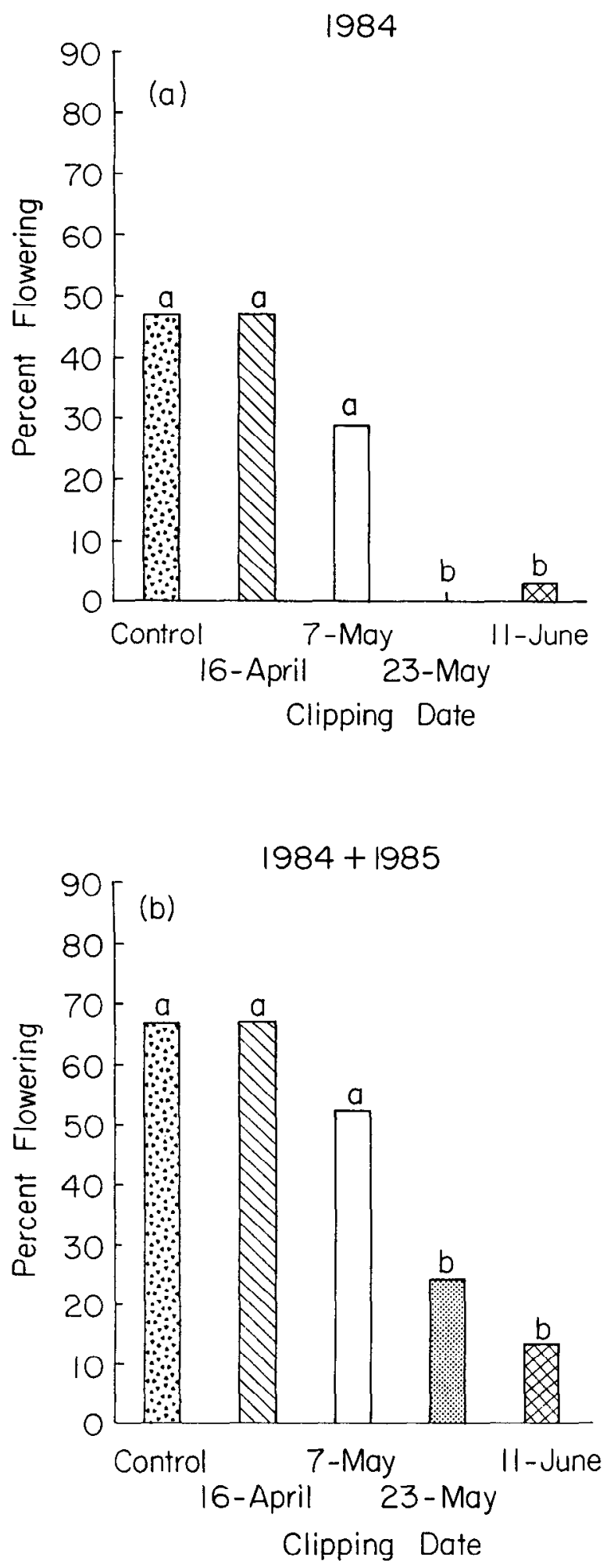

Fig. 6. Effect of time of clipping on mean cumulative percent flowering of dyers woad during 1984 (a) and during 1984 and 1985 combined. (b). Intensity of clipping and sample size are the same as in Fig. 5. Bars with different letters are significantly different at an $\alpha$ level of 0.05 . decline on a per plant basis (data not shown) and fruit weights were not affected by the time of clipping (data not shown). We have shown elsewhere (Farah et al. 1988) that achieving reductions in seed production of woad are crucial for its control since seed dormancy is minimal and only about $3 \%$ of the seedlings reach maturity.

A combined analysis (data not shown) of multiple and single clipping showed that a single late clipping at $90 \%$ intensity resulted in similar mortality and flowering responses as multiple clipping. Most importantly, the effects associated with clipping 4 times could not be distinguished from clipping once in mid June.

\section{Utilization Study}

To determine whether the timing and intensity of clippings were realistic, we monitored utilization of dyers woad by sheep on a nearby pasture. From 27 April until 18 May, only 48 out of 300 marked dyers woad plants ( $16 \%$ ) showed signs of utilization. Utilization of individually grazed plants ranged from 18 to $29 \%$, with an average of $39 \%$ of the above-ground tissue removed. This level of utilization did not significantly affect mortality, percent flowering, mean fruit production, or fruit weights (Table 2 ). The basal diameters and rosette diameters of grazed plants were greater than those of ungrazed plants (Table 2), which indicates that animals were selecting larger plants. The utilization study ended after 18 May, before the end of the growing season, because sheep switched their preferences to other forages entirely. Avoidance of dyers woad occurs at the time of maximum flowering stalk growth.

\section{Discussion}

As with many other cool-season range plant species in the temperate zones (Jameson 1963, Caldwell 1984), clipping damaged dyers woad more severely when it occurred later in the spring. In a single, aboveground clipping in a previous study conducted near our site (Fuller 1985), mortality increased and flowering decreased when a single above-ground clipping occurred on 25 June instead of 1 May 1982. Results from the treatments involving multiple and single clippings reported here indicate that clipping plants on or after 23 May (time of peak bloom) increased mortality and reduced flowering. Before this date, clipping $90 \%$ of aboveground phytomass twice, at bi-weekly intervals, did not affect survivorship or reproductive capacity. Fuller (1985) found that to significantly reduce flowering capacity and increase mortality before 23 May, dyers woads had to be clipped $5 \mathrm{~cm}$ below the ground surface. This suggests dyers woad damaged by clipping or grazing regenerates by activation of buds on the root crown and upper roots beyond the reach of sheep.

Casually managed sheep had little affect on mortality or seed production of dyers woad in the instance we monitored. Sheep there did not voluntarily utilize great amounts of dyers woad, even though the range was in poor condition.

The intensity and timing of grazing needed to significantly affect the mortality and reproductive capacity of dyers woad at our clipping site in good condition would probably result in substantial range deterioration because livestock prefer other, more desirable native forage species during the same period, and these other species are very susceptible to grazing damage at that time (West 1983).

More host-specific biological agents should be examined for use in controlling dyers woad. Unless there are some successes in using the rust (Puccinia thlaspeos) (Daines 1988), dyers woad will probably continue to increase in density on infested sites and spread more widely in the Intermountain West. 
Table 2. Percent mortality, percent fowering, mean fruit production per plant, fruit weights at the end of the 1984 growing season ( $n=30)$. Mean basal diameter, mean rosette diameter for grazed and ungrazed dyers woad plants on 18 May 1984 ( $n=22)$. Standard errors or $95 \%$ confidence limits, where appropriate, are shown in parentheses.

\begin{tabular}{|c|c|c|c|c|c|c|}
\hline Treatments & $\begin{array}{l}\text { Percent } \\
\text { Mortality }\end{array}$ & $\begin{array}{c}\text { Percent } \\
\text { Flowering }\end{array}$ & $\begin{array}{c}\text { Fruit } \\
\text { Number }\end{array}$ & $\begin{array}{l}\text { Fruit Weight } \\
\text { (g/ } 100 \text { fruits) }\end{array}$ & $\begin{array}{l}\text { Basal Diameter } \\
\text { (cm) }\end{array}$ & $\begin{array}{c}\text { Rosette Diameter } \\
(\mathrm{cm})\end{array}$ \\
\hline Ungrazed & 25 & 49 & 215 & .334 & $.34(.02)$ & $8.71(.42)$ \\
\hline Grazed & 19 & 51 & 240 & .351 & $.47(.04)$ & $11.03(.52)$ \\
\hline $\begin{array}{l}95 \% \text { confidence } \\
\text { intervals }\end{array}$ & & & $(143,311)$ & $(.311, .391)$ & & \\
\hline
\end{tabular}

\section{Literature Cited}

Brock, J.H. 1988. Livestock: Biological control in brush/weed management programs. Rangelands 10:32-33.

Caldwell, M.M. 1984. Plant requirements for prudent grazing. p. 117-152. In: Nat. Acad. Sci./Nat. Res. Council Developing strategies for rangeland management. Westview Press, Boulder, Colo.

Cochran, W.C., and G.M. Cox. 1957. Experimental designs. 2nd ed. Wiley, New York.

Daines, R. 1988. Natural rust offers hope for biocontrol of dyers woad. Utah Farmer-Stockman, August Issue, p. 6.

Evans, J.O., and R.L. Chase. 1981. Dyers woad control. EL-199. Utah State Ext. Serv., Logan, Utah.

Evans, J.O., and R.W. Gunnell. 1982. An evaluation of control strategies for dyers woad in crop and rangelands. Proc. West. Soc. Weed Sci. 35:32-33.

Farah, K.L. 1987. Autecological and grazing control studies of dyers woad (Isatis tinctoria L.) on northern Utah rangelands. Ph.D. Diss., Utah State Univ., Logan.

Farah, K.O., A.F. Tanaka, and N.E. Weat. 1988. Autecology and population biology of dyers woad (Isatis tinctoria). Weed Sci. 36:186-193.

Fuller, A.T. 1985. An autecological study of dyers woad (Isatis tinctoria L.) on Utah Rangelands. M.S. Thesis, Utah State Univ., Logan.
Jameson, D.A. 1963. Responses of individual plants to harvesting. Bot. Rev. 29:532-594.

King, W.O., and J.O. Evans. 1983. Effects of several foliar applied herbicides on the viability of dyers woad (Isatis tinctoria L.) seed. Proc. West. Soc. Weed Sci. 36:98-101.

Scifres, C.J. 1981. Selective grazing as a weed control method. p. 369-375. In: CRC handbook of pest management in agriculture Vol. II, Chemical Rubber Publ., Co., Orlando, Florida.

Soll Conservation Service. 1975. Soil survey of Box Elder Co. Utah: eastern part. USDA Soil Conserv. Serv., Salt Lake City, Utah.

Soil Conservation Service. 1985. Utah Range Site Guides. USDA Soil Conserv. Serv., Salt Lake City, Utah.

Sokal, R.R., and F.M. Rohr. 1981. Biometry: the principles and practices of statistics in biological research. 2nd ed. W.H. Freeman and Co., San Francisco.

Steel, R.G.D., and J.H. Torrie. 1980. Principles and procedures of statistics. McGraw-Hill Book Co., New York.

West, N.E. 1983. Western Intermountain sagebrush steppe, p. 351-374. In: N.E. West (ed.), Temperate deserts and semi-deserts. Elsevier Sci. Publ. Co., Amsterdam, Netherlands.

Young, J.A., and R.A. Evans. 1977. Dyers woad. Weeds Today (Fall, 1977):1.

Moving? Keep your publications arriving by sending us your new address as soon as you know it. Our address is 1839 York Street, Denver, Colorado 80206. 